low. 'Intraplate' would incorporate continental region of active tectonics such as south central Asia, in which surface rupture is relatively abundant. In the western United States alone, one can cite ten examples of intraplate surfacefaulting earthquakes outside the San Andreas fault system.

Continental crust covers an area of $2.1 \times 10^{8} \mathrm{~km}^{2}$, of which 'stable' crust (the Precambrian cratons and shields, Palaeozoic mountain belts and margins no younger than Palaeogene $(\sim 37 \mathrm{Myr}))$ comprises $\sim 1.32 \times 10^{8} \mathrm{~km}^{2} \quad(63 \%)$. Tectonically active crust, in which largescale faulting, mountain building or magmatic activity extends into the Cenozoic era (0-65 Myr) covers $\sim 7.3 \times 10^{7} \mathrm{~km}^{2}$ $(35 \%)$, with submerged continental plateaux providing the remaining $2 \%$.

This division of continental crust into active and stable components ${ }^{4}$ is certainly not the only one possible, and the term 'stable' is only relative, as large earthquakes do occur in SCR crust. But the need for some such distinction is highlighted by the great range of surface faulting rates observed in continental regions. An alternative to using the tectonic age of the crust as a means of distinguishing relatively active from relatively stable regions is just becoming available from the satellite geodetic techniques of $\mathrm{VLBI}^{5}$ (very-long-baseline interferometry), SLR $^{6}$ (satellite laser ranging) and GPS $^{7}$ (Global Positioning System). These and other preliminary results suggest that SCR deform at a strain rate of $10^{-9}-10^{-10} \mathrm{yr}^{-1}$ - orders of magnitude less than those that characterize active intraplate $\left(10^{-7}-10^{-9} \mathrm{yr}^{-1}\right)$ and plate-boundary zones $\left(10^{-5}-10^{-6}\right.$ $\left.\mathrm{yr}^{-1}\right)$. As one would expect, these large differences in strain rate are reflected in the observed seismicity ${ }^{8}$.

Stable continental (and oceanic) crust is our closest approximation to the platetectonic ideal of monolithic plates interacting, reacting and deforming only at their boundaries. This is not true of all intraplate regions. In cases, such as the study of surface faulting, where the term 'intraplate' combines two quite different species of crust, it should be avoided.

ARCH C. JOHNSTON

Center for Earthquake Research,

Memphis State University,

Memphis, Tennessee 38152, USA

1. Adams, J., Wetmiller, R. J., Hasegawa, H. S. \& Drysdale, J. Nature 352, 617-619 (1991)

2. Crone, A. J. Nature 352, 570 (1991).

3. Johnston, A. C. \& Bullard, T. Seismol. Res. Lett. 61 152-153 (1990).

4. Johnston, A. C. \& Kanter, L. R. Scient. Am. 262(3), 68-75 (1990)

5. Ward, S. N. J. geophys. Res. 95, 21965-21981 (1990).

6. Smith, D. E. et al. J. geophys. Res. 95, 22013-22041 (1990)

7. Billiris, H. et al. Nature 250, 124-129 (1991).

8. Johnston, A. C. in Earthquakes at North-Atlantic Passive Margins: Neotectonics and Postglacial Rebound (eds Gregersen, S. \& Basham, P. W.) 299-327 (Kluwer. Dordrecht, 1989)

\title{
Methane and Milankovitch cycles
}

SIR - Crowley suggests ${ }^{1}$ that the northern summer radiation maxima may have partly controlled atmospheric methane levels ${ }^{2}$ by enhancing methane output by high-latitude ecosystems. But this idea neglects what is known of major controlling factors on high-latitude production.

At present, the high-latitude wetlands rely for their capacity for methane production on the anaerobic, waterlogged conditions which are assoicated with, and strongly reinforced by, extensive peat deposition ${ }^{3}$ (and Clymo, personnal communication). From palaeoevidence ${ }^{4}$ it seems that an extensive high-latitude complement of anaerobic peat wetlands would have taken millenia to form, after the climate initally became suitable for them. For example, when considering the late glacial-early Holocene methane rise and peaks (12 and $9 \mathrm{kyr}$ ), the necessary anaerobic conditions may not have been extensive in the high northern latitudes at the time of the summer maximum.

The main Siberian peat-basins and other wetlands have progressively spread from very localized nuclei to form an extensive blanket during the Holocene ${ }^{4}$. The greater growing season evaporation potential and a resulting summer lowering of water tables may well have favoured less waterlogging at the summer radiation maximum. Large areas of the high latitudes of the Northern Hemisphere that are currently covered by peatlands and are now major methane producers were still under ice at the times of the Early Holocene methane rise and peaks (patricularly

\section{Patterns of population spread}

SIR - The recent News and Views article $^{1}$ accompanying our paper ${ }^{2}$, and various press reports about our work, could have provided a false impression about earlier work. As we pointed out ${ }^{2}$, the hypothesis that agriculture in Europe spread by demic diffusion was first proposed by Ammerman and CavalliSforza $^{3-5}$. The theory predicts genefrequency clines in an approximate northwest-southeast direction in Europe. Cavalli-Sforza's group first described $^{6}$ such clines based on synthetic variables obtained by principal components analysis, but they did not test the statistical significance of these trends. Our laboratory first tested the statistical significance of patterns by means of spatial autocorrelation analysis. We confirmed the existence of northwest-southeast clines for gene frequencies but not for cranial variables. Our latest paper ${ }^{2}$ reported a method for testing the genetic evidence against the spe- the 12-kyr peak). In areas that the ice had already vacated, the generalized picture of deglaciating landscapes being pock-marked by lakes and dissected by meltwater streams does not necessarily point to extensive anaerobic conditions.

In northwestern Europe, sedimentary evidence suggests that the late-glacial and early Holocene (12-9 kyr) landscapes were lacking in extensive anaerobic and peat-forming conditions. Only as the Holocene proceeded did extensive bogs begin to form naturally in this area. Thus, we should perhaps think in terms of the main development of the northern high-latitude methane source having a lag period, which means that it is unlikely to reach its maximum potential for thousands of years, until after each insolation peak has passed.

Department of Plant Sciences,

J. M. ADAMS

University of Cambridge,

Downing Street,

Cambridge CB2 3EA, UK

H. FAURE

Laboratoire de Géologie

N. PETIT-MAIRE

du Quaternaire,

CNRS, Case 907,

Luminy, F-13288 Marseille

Cedex 9 ,

France

1. Crowley, T. J. Nature 353, 122-123 (1991)

. Chappellaz, J., Barnola, J. M. Raynaud, N., Koroketvich, Y. S. \& Lorius, C. Nature 345, 127-131 (1990)

3. Matthews, E. \& Fung, I. Global Biogeochem. Cycles 1. 61-86 (1987)

4. Neustadt, M. I. in Late Quaternary Environments of the Soviet Union (ed. Velichko, A. A.) 201-206 (Longman, London, 1984) cific pattern of neolithic spread. ROBERT R. SOKAL CHESTER WILSON

Department of Ecology and Evolution, State University of New York, Stony Brook, New York 11794-5245, USA

Department of Preventive Medicine, Health Sciences Center, State University of New York, Stony Brook, New York 11794-8036. USA

1. Jones, J. S. Nature 351, 97-98 (1991).

2. Sokal, R. R., Oden, N. L. \& Wilson, C. Nature 351 143-145 (1991)

3. Ammerman, A. J. \& Cavalli-Sforza, L. L. in The Explanation of Culture Change (ed. Renfrew, C.) 343-358 (Duckworth, London, 1973).

4. Ammerman, A. J. \& Cavalli-Sforza, L. L. in Transforma tions: Mathematical Approaches to Culture Change (eds Renfrew, C. \& Cooke, K. L.) 275-294 (Academic, New York, 1979).

5. Ammerman, A. J. \& Cavalli-Sforza, L. L. The Neolithic Transition and the Genetics of Populations in Europe (Princeton University Press, 1984).

6. Menozzi, P.. Piazza, A. \& Cavalli-Sforza, L. L. Science 201, 786-792 (1978) 